\title{
THE LEGEND AND SHRINE OF SAINT TrIDUANA*
}

\author{
BY \\ JOHN FOSTER
}

Leeds

A familiar feature in the eye hospitals of the Mediterranean littoral is the statue or picture of St. Lucia of Syracuse, holding her eyes on a plate. This stylized portrayal dating back to the 12th century is based on the legend that "when pestered by a would-be suitor she performed an auto-evulsion of her eyes and sent them to him "- a literal translation into action of St. Matthew, chapter 18, verse 9. It might be added that while this legend is not given in the catholic encyclopaedia, and at least one student of St. Lucia's iconography regards it as a later accretion due to confusion with the Beata Lucia Casta of Jerez, it appears to be this story which has made her the patron saint of ophthalmology in that part of the world.

It is interesting that the same legend, though very much less widely known, is recorded of a Scottish saint, and that there is evidence that her shrine still exists near Edinburgh.

The literature of the legend is extremely exiguous, the sources of my information being Baring Gould (1872-89), Burnett (1908), and the present incumbent, the Rev. Robert Black Notman, B.D.

According to the breviary of Aberdeen, the blessed and gracious virgin, Saint Triduan, was born at Colosse and landed in Scotland from Constantinople in the company of Saint Regulus or Rule about A.D. 337. These saints brought with them the relics of Saint Andrew, the patron saint of Scotland, an event for ever commemorated by St. Andrews on the coast of Fife.

Subsequently (whilst living an eremitic life with other virgins at Rescoby in Forfarshire), as she was of illustrious birth, of an elegant form, and by nature of a pre-eminently virtuous disposition, Saint Triduan attracted the attentions of the local prince, Nectaneus or Nectan, who desired to marry her. She questioned the messenger sent to her by the Prince, and hearing that he was chiefly attracted by the transcendent beauty of her eyes, she replied, "What he asks of me he shall obtain "; and retiring into a secret place she plucked out her eyes, transfixed them on a wooden pin, and held them out to the messenger, saying, "Accept what your prince desires". Thereafter she made her abode at Lestalryk, i.e. Restalrig in Lothian, some 2 miles from Edinburgh, where she devoted the rest of her life to fasting and prayer.

*Received for publication May 15, 1953. 
Between this early legend and the earliest mention of a shrine of Saint Triduana, a long lapse of time occurs, for the next information available comes from the chartularies of the Priory of St. Andrews, which mention the church of St. Triduana at Restalrig in 1178. The golden years of the little church began in 1477, when James III of Scotland made it a Chapel Royal by endowing a chaplaincy, and 11 years later Pope Innocent VIII granted the petition of the same king that the church at Restalrig be erected into a Collegiate church with eight Prebendaries under a Dean. Further endowments in 1496 and 1527 came from James IV and V. Unfortunately, no description of the building itself has come down to us, but apparently it had 32 altars, including a shrine of Saint Triduana. In 1545 it is recorded that a sacrist received " a chamber and garden beside the church with the offerings made to the altar to maintain the lower aisle of the church, the altar of Saint Triduana therein situate, the books, wax candles, and other necessaries".

A verse from a poem by Sir David Lyndsay (1486-1555) suggests that about this time the shrine was a popular place of pilgrimage. His corruption of the name to Tredwells (later still Traddles) is interesting as conveying the first suggestion of a well.

\section{It was too lang for tyll discryfe \\ Sanct Francis with his woundes fyfe \\ Sanct Tredwells als there may be sene \\ Quelk on ane prik hath both hir ene . \\ To Sanct Tredwell to mend their eine.}

The shadows were gathering around the church, however; Dr. John Sinclair, who became dean in 1545 , was described by one of his contemporaries as " a worldly wise man and not ungodly in understanding the truth", but he excited very different feelings in the breast of John Knox, the outspoken reformer, who wrote of "that perfyt hypocryte John Sinclare . . . . . blind of ane eie in his body, but of boith in his saule". As the present incumbent of Restalrig writes: "it is interesting to speculate what part this personal antipathy played in the utter destruction of the fabric", for in 1560 one of the first decrees of the general assembly of the Presbyterian Church of Scotland was that: " the Kirk of Restalrig as a monyment of idolatrie be raysit and utterly casten downe and destroyed". This edict was carried out almost to the letter, for, with the exception of the East window and the walls of the chancel, the stones were carried away to rebuild the Netherbow port (gate) of Edinburgh city. For nearly 300 years the church remained a gaunt ruin; one engraving shows one corner only standing, and nearby the hexagonal building, then believed to be a chapter or assembly house, although such would be unusual in a collegiate church.

In 1837 the church was rebuilt by the Restalrig Friendly Society and passed into the hands of the Established Church of Scotland. At this time the hexagonal building, which was believed to be a chapter house or mausoleum, 
was roofless and filled with earth to a height of $12 \mathrm{ft}$. In 1907 the earth was excavated at the instance of the Earl of Moray, on whose land the chapel stood, and according to Ross (1912) an attempt was made to asphalt the floor to exclude a constant rise of water. Finally it became obvious that this was impossible as the rise was due not to seepage, but to a spring under pressure, and the floor remained covered by a foot of water. It then became apparent that the building closely resembled the wellhouse of St. Margaret nearby, that a built-up arch $12 \mathrm{ft}$. high on the north side had probably led into the church, and that, therefore, the building had originally been the well-house and chapel of the Blessed Virgin of Lestalryk. The roof was repaired and a statue of the Saint holding a thorn bush with her eyes transfixed on the branches was mounted thereon (Figure), but the statue is now so smoke-blackened that details are not clearly perceptible. About half a mile away stands the Roman Catholic church of Saint Triduana, from which processions are made to the well on her holy day, October 8.

If we accept the legend, it would appear, by analogy with that of Saint Lucia, that British ophthalmologists can claim a patron saint of their own.

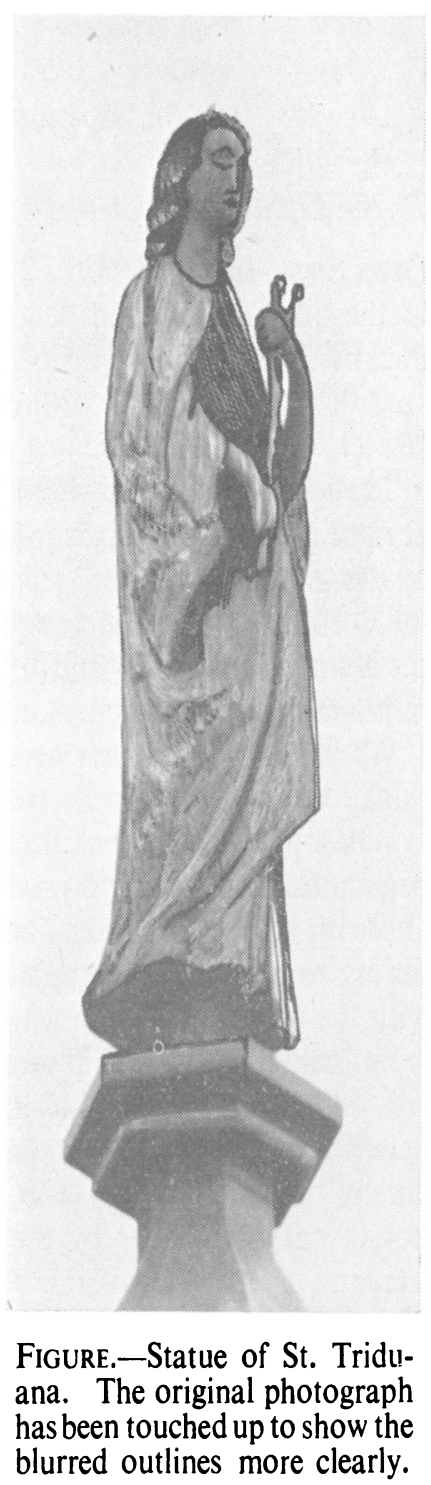

\section{REFERENCES}

BURNeTt, W. (1908). "Transactions of the Scottish Ecclesiological Society, 1907-8", 2, (Part 2), 275.

Gould, S. BARING (1872-89). "The Lives of the Saints", 17 vols. Hodges, London.

LyNDSAY, D. (1931-36). "Works", 4 vols, ed. by D. Hamer for the Scottish Text Society. Charteris, Edinburgh.

Notman, R. B. (1937). "Restalrig Parish Church. A Short Account of its History and Traditions". Law, Leith.

Ross, T. (1912). "Transactions of the Edinburgh Architectural Association for 1908-1909", 7,55 . 